\title{
Industrial Scale-up of Fiber Recovery Technology from Mixed Office Waste Fine Screen Rejects
}

\author{
Zhen-Hua Su, ${ }^{\text {a,b,c }}$ Shu-Jie Fan, ${ }^{\text {a,b }}$ Yu Zhang, ${ }^{\text {a, }}$ Chao Tian, ${ }^{\text {a,b }}$ Chen Gong, ${ }^{\text {a,b }}$ Jian-Ping \\ $\mathrm{Ni},{ }^{\mathrm{a}, \mathrm{b}}$ Bin Yang, ${ }^{\mathrm{a}, \mathrm{b}}$ Feng Peng, ${ }^{\mathrm{c}}$ Mika Korkko, ${ }^{\mathrm{d}}$ and Mohamed S. Mahmoud ${ }^{\mathrm{e}}$ \\ Industrial-scale testing was performed for fine screen reject recovery \\ technology with a mixed office waste (MOW) pulping line. Results showed \\ that the recovery system removed macrostickies and dirt specks with an \\ efficiency of $95.7 \%$ to $98.3 \%$ and $51.5 \%$ to $76.8 \%$, respectively. These \\ results were not affected by the running consistency (0.26\% to $1.44 \%)$. \\ The recovery system improved the physical strength of the pulp. Relative \\ to untreated rejects, the tensile index increased $5.1 \%$ to $15.2 \%$, the tear \\ index increased $6.6 \%$ to $11.4 \%$, and the breaking index increased $6.6 \%$ to \\ $25.7 \%$. Running consistency had no obvious effects on tensile strength \\ and tear strength, but bursting strength increased with increasing running \\ consistency $(\%)$. The volume energy consumption $(y)$ increased with \\ increasing running consistency $(x)$, and a linear relationship of $y=0.73 x+$ \\ $4.2191\left(R^{2}=0.9466\right)$ was observed. The specific energy consumption $(y)$ \\ of the pulp decreased with increasing running consistency $(x)$, and the \\ relationship could be expressed as $y=499.67 x^{0.906}\left(R^{2}=0.9959\right)$.
}

Keywords: Secondary fiber; Fine screen reject; Fiber recovery; Macrostickies; Dirt specks; Physical strength

Contact information: a: China National Pulp and Paper Research Institute, P. O. Box 100102, Beijing, China; b: National Engineering Lab for Pulp and Paper, P. O. Box 100102, Beijing, China; c: Beijing Key Laboratory of Lignocellulosic Chemistry, Beijing Forestry University, P. O. Box 100083, Beijing, China; d: Haarla Oy, Pyhajarvenkatu 5A, FI-33200 Tampere, Finland; e: Sanitary and Environmental Institute (SEI), Housing and Building National Research Center (HBRC), P. O. Box 1770, Cairo,Egypt; *Corresponding author: mika.korkko@haarla.fi,mphdmicro2012@yahoo.com

\section{INTRODUCTION}

Waste paper is an important renewable resource, and its recycling is greatly beneficial to the economy, society, environmental protection, and resource utilization. Due to a desire to reduce paper raw material shortage and forest resource scarcity, the recycling and utilization of waste paper has long been an issue of great concern in China. The amount of recycled waste paper has increased each year. Since 2000, the amount of waste paper used has soared at a rate of over 3 million tons per year (Fan et al. 2018; Su et al. 2019). By 2016, waste pulp consumption in China reached 63.29 million tons (China Paper Association 2017). Waste paper consumption accounts for $65 \%$ of total pulp consumption, which is much higher than that of wood pulp (29\%) and non-wood pulp (6\%) (China Paper Association 2017). As such, waste paper has become the main raw material of the pulp and paper industry in China. Waste paper products include colored newsprint, high-strength corrugated base paper, carton paper, coated white cardboard, printing paper, and domestic paper.

In 2017, to implement the plan of the China State Council on "the reform of the 
administration system for the import of solid waste" (General Office of the State Council of the People's Republic of China 2017), the Ministry of Environmental Protection of the People's Republic of China (2017) released a series of policies that aim to increase the use of fiber raw materials. Therefore, it is essential to study methods of improving waste paper utilization efficiency. In waste paper pulping, a large amount of reject is discarded during the purification process, in which fine screen reject accounts for $2 \%$ of raw materials. Although most fine screen reject consists of long fibers of high quality, it can only be discharged from the system and utilized to produce low-value products due to its high macrostickies content. This wastes fiber raw materials, adds to solid waste pollution, and increases the cost of solid waste treatment. Much research has been conducted on the properties of waste paper pulping and deinking (Chen 2003; Long and Wen-Ying 2014). Results indicate that high-frequency decontamination can be used in combination with flotation to recover fine screen reject fibers in mixed office waste (MOW) and old newspapers (ONP). The removal rates of macrostickies and dirt specks reached over $90 \%$ and $70 \%$, respectively (Su et al. 2019). The recovery rate of fibers was about $80 \%$. In addition, paper tensile resistance and breaking resistance can be improved by $20.2 \%$ to $23.5 \%$ and $29.3 \%$ to $32.3 \%$, respectively (Su et al. 2018a, 2019). When treating ONP fine screen rejects, the removal rate of macrostickies and dirt specks can reach over $80 \%$ and $53.0 \%$, respectively, and the removal rate of residual ink can reach over $25 \%$ (Su et al. $2018 \mathrm{~b}$ ). Further, the tensile strength, tear-resistance, and breaking resistance increased $95.4 \%, 16.3 \%$, and $84.3 \%$, respectively (Su et al. 2018b).

In this study, the pilot-scale magnified system was used in the MOW line to study the industrial recovery rate of fibers, the removal rate of macrostickies and dirt specks, and the tensile resistance, tear-resistance, and breaking resistance of paper. Samples were taken continuously with different running consistencies, and the impact of running consistency on the removal of macrostickies, the removal of dirt specks, and pulp strength were studied to provide a reference and promote industrial adoption of similar methods.

\section{EXPERIMENTAL}

\section{Materials}

The fine screen rejects were sampled from the MOW paper mill production line, Dongguan City, Guangdong Province, China, and the physical test results are summarized in Table 1.

Table 1. Characteristics of Fine Screen Reject

\begin{tabular}{|c|c|c|c|c|c|}
\hline \multirow{2}{*}{$\begin{array}{c}\text { Brightness } \\
(\%)\end{array}$} & \multirow{2}{*}{$\begin{array}{c}\text { ERIC } 700 \\
\text { (ppm) }\end{array}$} & Macrostickies & Dirt Specks & \multirow{2}{*}{$\begin{array}{l}\text { Ash } \\
(\%)\end{array}$} & \multirow{2}{*}{$\begin{array}{c}\text { R200 } \\
(\%)\end{array}$} \\
\hline & & $\left(\mathrm{mm}^{2} / \mathrm{Kg}\right)$ & $\left(\mathrm{mm}^{2} / \mathrm{m}^{2}\right)$ & & \\
\hline 65.2 to 71.8 & 93.0 to 98.0 & 6027 to 23413 & 1293 to 3640 & 14.0 to 14.8 & 86.8 to 91.8 \\
\hline
\end{tabular}

\section{Analytical Methods}

Macrostickies were analyzed with a master screen-type instrument (Pulmac Screen MSA-XLQ; Cowan Technologies Inc., Montpelier, VT, USA) and a scanning system Spec*Scan2000 (Apogee, Norwood, MA, USA) according to TAPPI T277 pm-99 (1999). Twenty hand sheets were prepared for dirt speck analysis with an image analysis system 
according to TAPPI T563 om (2012). For ash content analyses, the filter papers for the consistency measurement were incinerated at $525^{\circ} \mathrm{C}$. Brightness, residual ink, fiber length, and physical strength were analyzed according to ISO 2470 (2016), TAPPI T567 om (2009), TAPPI T233 cm (2006), and TAPPI T220 sp-10 (2010), respectively.

\section{High-frequency dispersion}

Dispersion was performed using a magnified-scale high-frequency dispergator 23 (ZRI Haarla Oy, Tampere, Finland), which consisted of a stator and a rotor with a frequency of $300 \mathrm{~Hz}(18000 \mathrm{rpm})$. The fine screen reject was dispersed via continuous feeding into the center of the stator at a pressure of approximately 1 bar to 2 bars. During dispergator operation, the gap between the stator and rotor was approximately $1 \mathrm{~mm}$. A manual valve was used to control the through flow and the pressure, which was 1 bar. All parameters, such as flow, pressure, concentration, and energy consumption were automatically monitored by the system.

\section{Flotation}

An HG continuous flotation cell was used for the flotation of accept pulp from the high-frequency dispergator. The airflow was kept constant for the entire experimental process. No additional chemicals were used, as the samples contained residual flotation chemical agents. Samples of each batch and the removed froth were taken before and after flotation for analysis. The fine screen reject recovery process is shown in Fig. 1.

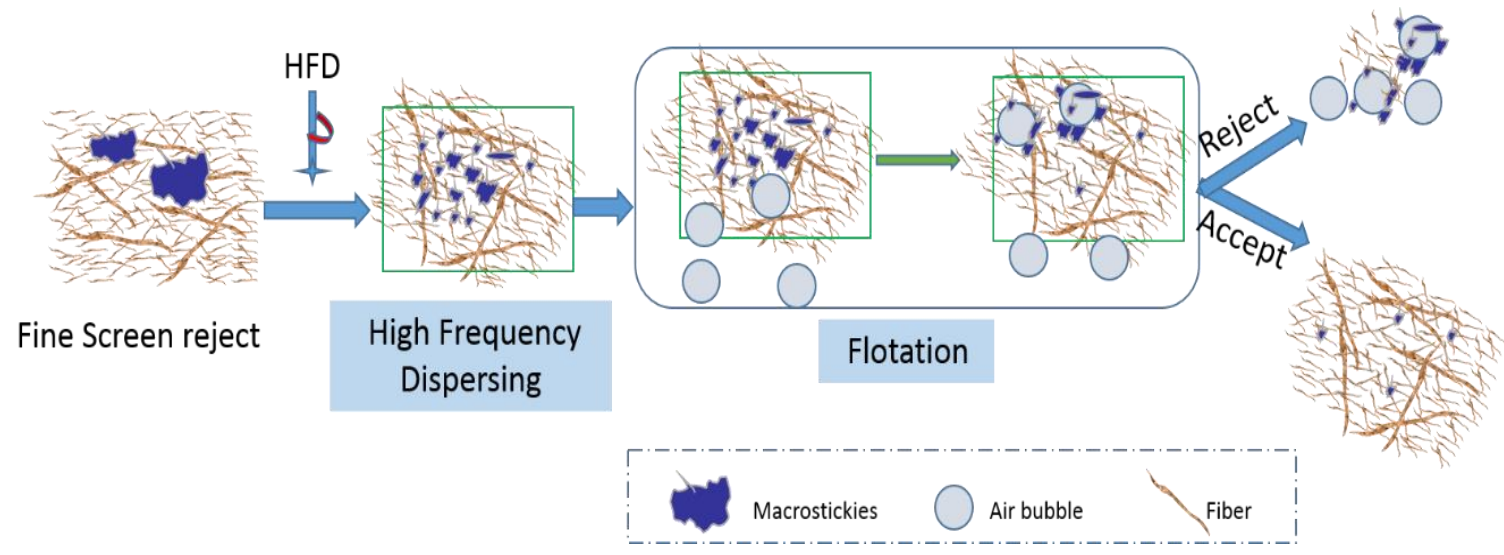

Fig. 1. The Fine Screen Reject recovery process

\section{Handsheet Making}

Handsheets of $60 \mathrm{~g} / \mathrm{m}^{2}$ were made and dried in a RK-3A Rapid-Kothen sheet former (PTI Laboratory Equipment, Vorchdorf, Austria).

\section{RESULTS AND DISCUSSION}

\section{Removal of Macrostickies}

Macrostickies control is essential during the fine screen reject treatment process, as high macrostickies content is the biggest obstacle to the reuse of fine screen reject. To investigate the effect of fine screen reject recovery system on the removal of macrostickies, 
several rounds of trials were conducted with different consistencies $(0.26 \%, 0.55 \%, 0.62 \%$, $1.36 \%$, and $1.44 \%$ ). Untreated samples, dispersed samples, and dispersed and floated samples were taken for each consistency condition, and their macrostickies contents were analyzed. The content and size distributions are presented in Figs. 2 and 3, respectively.

Figure 2 shows that the quality of the fine screen reject discharged from the production line in the different periods fluctuated greatly. The original macrostickies content of the samples ranged from $6027 \mathrm{~mm}^{2} / \mathrm{kg}$ to $23413 \mathrm{~mm}^{2} / \mathrm{kg}$, but decreases of $48.7 \%$ to $80.9 \%$ were observed in macrostickies content. Although the original macrostickies contents and the macrostickies removal rate varied greatly due to dispersion, the overall removal rate of macrostickies after flotation with a reject rate of approximately $25 \%$ ranged from $95.7 \%$ to $98.3 \%$. In addition, the consistency of fine screen reject during dispersion had no remarkable effect on macrostickies removal efficiency. The macrostickies size distribution $(0.26 \%, 0.55 \%, 0.62 \%, 1.36 \%$, and $1.44 \%)$ shown in Fig. 3 is represented in plots A, B, C, D, and E, respectively. The high-frequency dispersion had a noticeable effect on macrostickies larger than $0.25 \mathrm{~mm}^{2}$ regardless of running consistency. With running consistencies of $0.26 \%, 0.55 \%, 0.62 \%, 1.36 \%$, and $1.44 \%$, the content of large-sized macrostickies (> $0.25 \mathrm{~mm}^{2}$ ) decreased $86.1 \%, 82.7 \%, 87.6 \%, 77.1 \%$, and $92.9 \%$, respectively, during dispersion. For $0.26 \%$ running consistency, a decrease from 4323 $\mathrm{mm}^{2} / \mathrm{kg}$ to $600 \mathrm{~mm}^{2} / \mathrm{kg}$ was observed. For $0.55 \%$ running consistency, a decrease from $5315 \mathrm{~mm}^{2} / \mathrm{kg}$ to $918 \mathrm{~mm}^{2} / \mathrm{kg}$ occurred. For $0.62 \%$ running consistency, a decrease from $20781 \mathrm{~mm}^{2} / \mathrm{kg}$ to $2587 \mathrm{~mm}^{2} / \mathrm{kg}$ was observed. For $1.36 \%$ running consistency, a decrease from $5722 \mathrm{~mm}^{2} / \mathrm{kg}$ to $1312 \mathrm{~mm}^{2} / \mathrm{kg}$ was observed. For $1.44 \%$ running consistency, a decrease from $17776 \mathrm{~mm}^{2} / \mathrm{kg}$ to $1260 \mathrm{~mm}^{2} / \mathrm{kg}$ occurred. However, high-frequency dispersion had no obvious effect on the removal of macrostickies smaller than $0.25 \mathrm{~mm}^{2}$. The rubbing action that occurs during kneading may modify the shape of macrostickies and cause them to become more spherical, and the high-speed dispersers produce more impacts, which lead to breakup of the particles (Su et al. 2018a,b). The results indicate that the dispersion effectively breaks the large contaminants into smaller pieces.

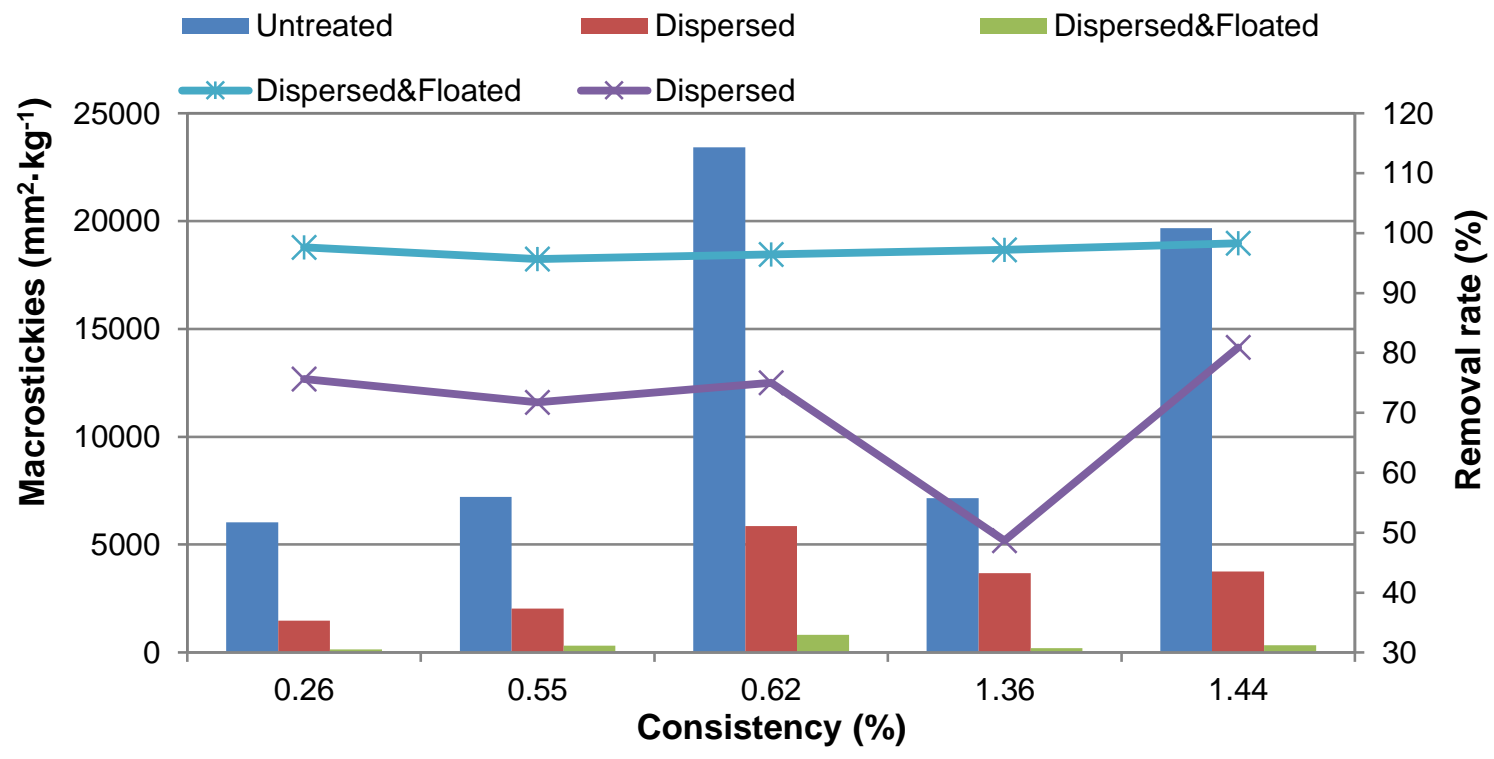

Fig. 2. The macrostickies contents under different consistencies in the screen reject recovery process

Su et al. (2020). "Fiber recovery from screen rejects," BioResources 15(3), 6420-6430. 

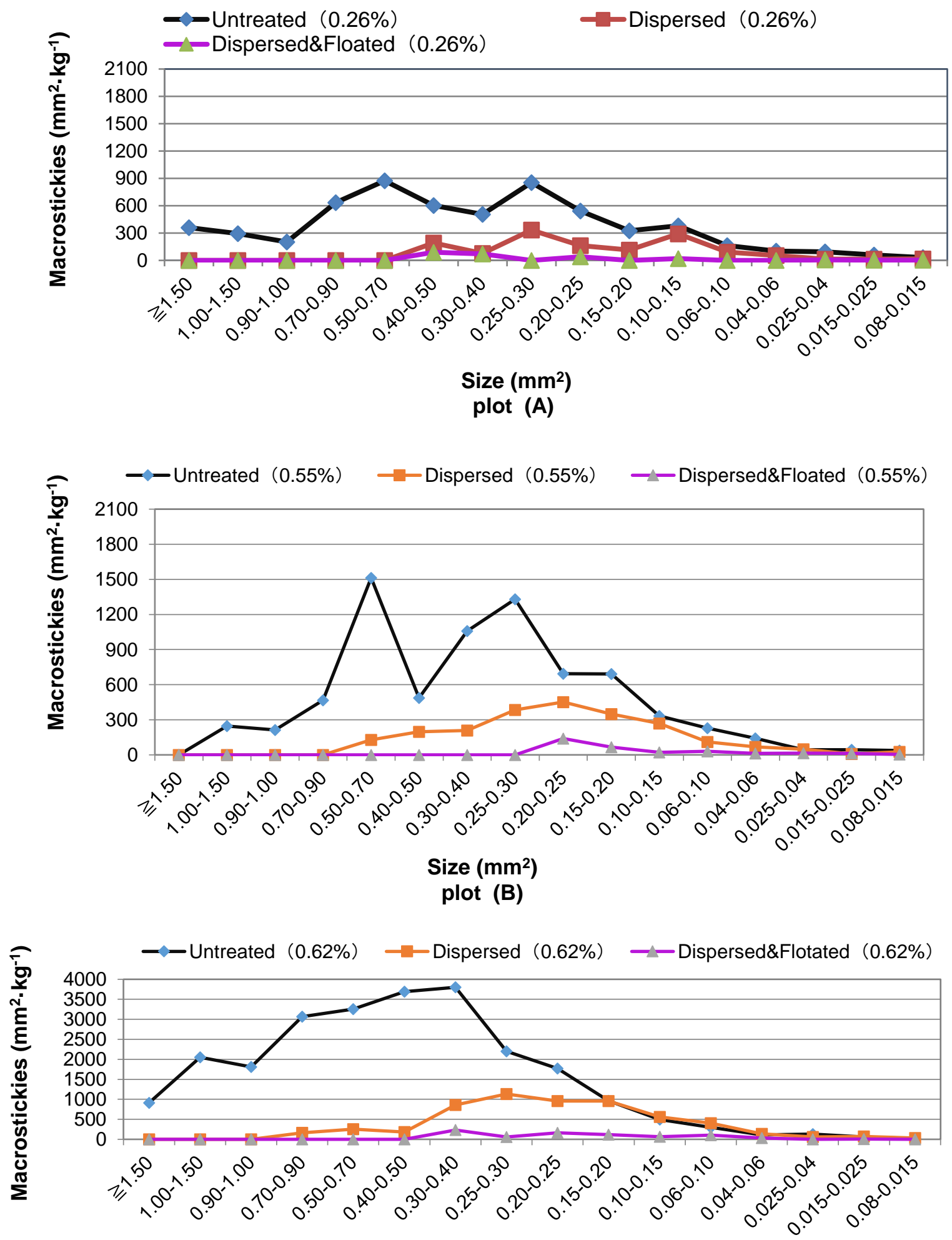

\section{Size $\left(\mathrm{mm}^{2}\right)$ \\ plot (C)}

Su et al. (2020). "Fiber recovery from screen rejects," BioResources 15(3), 6420-6430. 6424 

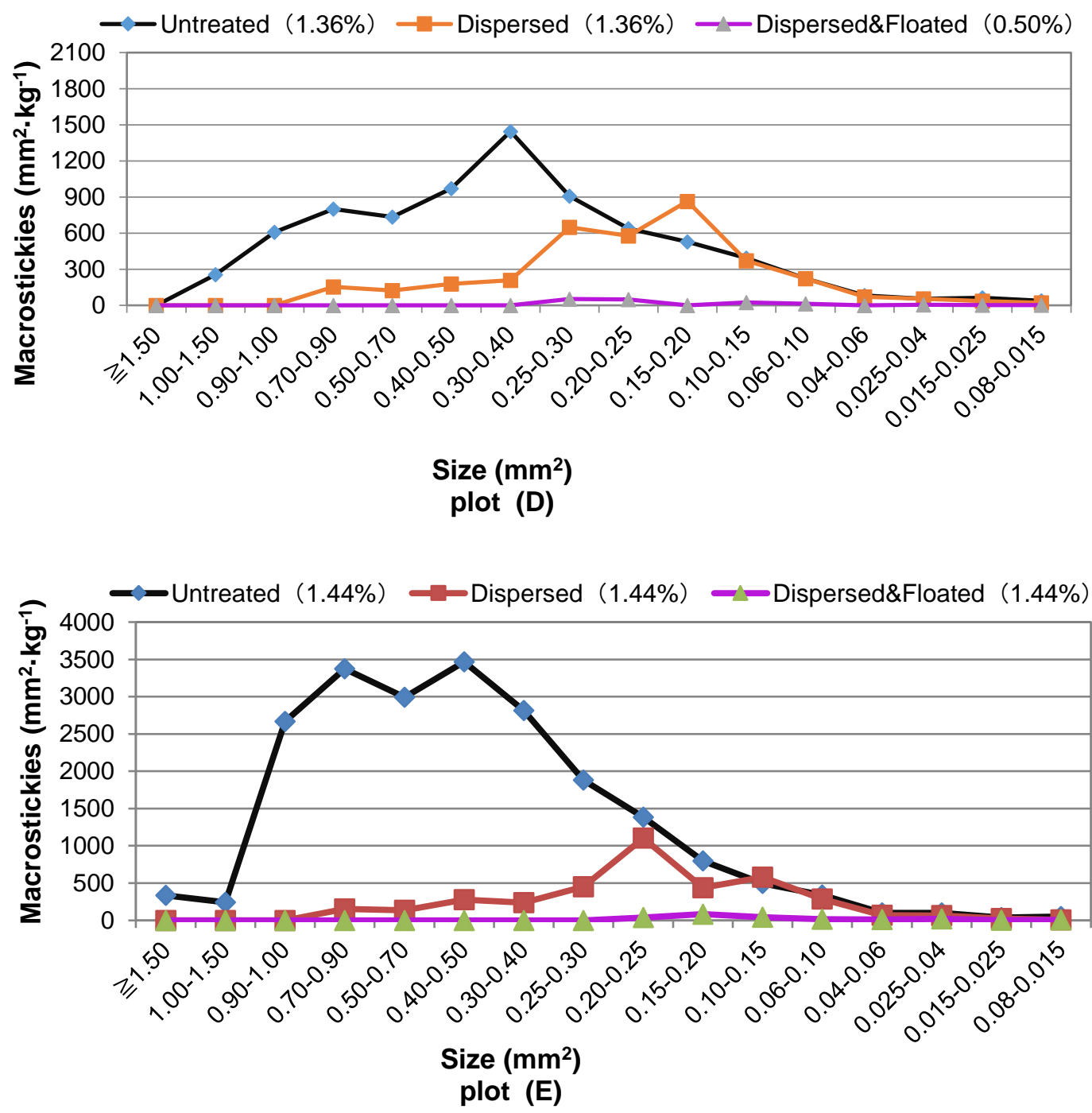

Fig. 3. Plots $A, B, C, D$, and $E$ describe macrostickies size distributions under different consistencies $(0.26 \%, 0.55 \%, 0.62 \%, 1.36 \%$, and $1.44 \%)$, respectively

Stickies became attached to air bubbles and rose to the surface of the flotation cell with the bubbles, which allowed their removal from the system. This study suggested that the improved removal of large contaminants in flotation may have been due to the newly formed or cleaned surface produced by dispersion (Su et al. 2018a,b). In addition to size reduction, high-frequency dispersion may have also cleaned and activated the surfaces of the contaminants, which improved their adhesion to the bubble surfaces and their ability to float. For all running consistencies, the removal rate of macrostickies larger than $0.25 \mathrm{~mm}^{2}$ was over $96.2 \%$, and the removal rate of macrostickies smaller than $0.25 \mathrm{~mm}^{2}$ was above $86.3 \%$. Over $75 \%$ of the fine screen reject treated by the fiber recovery system could be recycled.

\section{Removal of Dirt Specks}

Dirt specks are also a problem in the recycling of fine screen rejects. The dirt specks of the samples from the inlet and outlet of the high-frequency dispergator and floatation 
cells under different running consistencies were analyzed to evaluate the effect of the process on dirt speck removal. The results are presented in Fig. 4.

Figure 4 shows that the original dirt speck contents of fine screen reject varied from $1293 \mathrm{~mm} / \mathrm{m}^{2}$ to $3640 \mathrm{~mm}^{2} / \mathrm{m}^{2}$ on the MOW fiber line. Running consistency and original dirt speck content had no noticeable effects on the dirt speck removal efficiency of the fiber recovery system. Dirt speck removal rates of $41.0 \%$ to $50.8 \%$ were observed after highfrequency dispersion. High-frequency dispersion had a marked effect on large dirt specks (>0.1 $\mathrm{mm}^{2}$ ), and the removal rate reached $49.0 \%$ to $62.8 \%$. In addition, flotation had a dirt speck removal rate of $7.7 \%$ to $26.2 \%$ without obvious selectivity for dirt speck size, which was consistent with the results of Su et al. (2018b). These results indicated that dirt specks, particularly those large in size, were fragmented into smaller particles, and dispersion caused some of the dirt specks to fail to be measured. Further, some of dirt specks were removed with the flotation rejects by subsequent floatation.

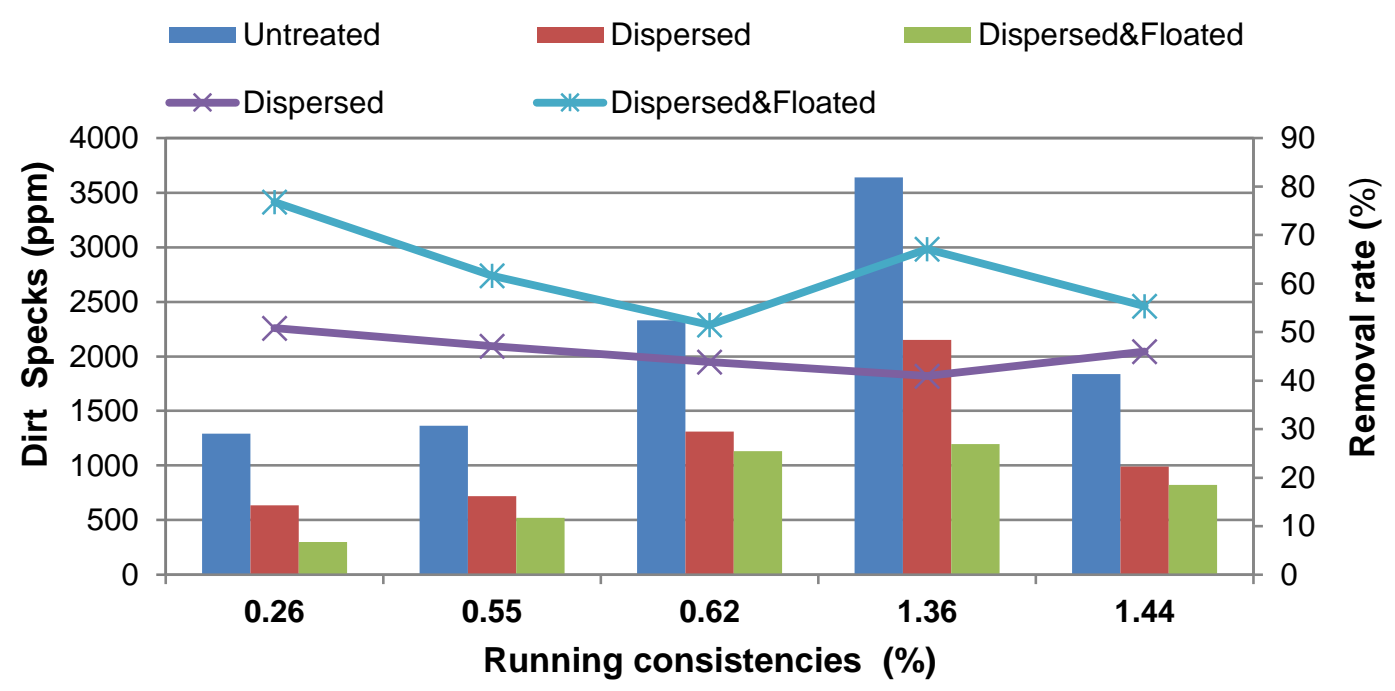

Fig. 4. The dirt speck contents with different running consistencies $(0.26 \%, 0.55 \%, 0.62 \%$, $1.36 \%$, and $1.44 \%)$

\section{Effects on Pulp Strength}

The physical properties of the different samples during the recovery process were tested under standard atmospheric conditions $(50 \pm 2 \%$ relative humidity and a temperature of $23 \pm 1{ }^{\circ} \mathrm{C}$ ) to investigate the effect of high-frequency dispersion and flotation on the quality of recovered pulp. The results are presented in Figs. 5, 6, and 7.

Figure 5 shows that the tensile strength of the samples increased $5.3 \%$ to $19.5 \%$ from $24.2 \mathrm{~N} \cdot \mathrm{m} \cdot \mathrm{g}^{-1}$ to $27.6 \mathrm{~N} \cdot \mathrm{m} \cdot \mathrm{g}^{-1}$ to $28.0 \mathrm{~N} \cdot \mathrm{m} \cdot \mathrm{g}^{-1}$ to $31.6 \cdot \mathrm{m} \cdot \mathrm{g}^{-1}$, relative to paper made from the unmodified fine screen rejects, after high-frequency dispersion with different running consistencies, but the influence of floatation on tensile strength was not clear. Figure 6 shows that the average improvement in samples was over 12\% after highfrequency dispersion and flotation, which showed no noticeable correlation with running consistency. Figure 7 shows that the burst strength of the samples increased $6.6 \%$ to $25.7 \%$ after high-frequency dispersion and flotation, and burst strength was found to increase with increased running consistency. This result indicated that high-frequency dispersion acted 
on the macrostickies and dirt specks and had a mechanical effect on the fibers, which allowed bonding between fibers with more exposed hydrogen bonds. This finding was supported by the increased beating degree of the samples of approximately $2{ }^{\circ} \mathrm{SR}$. The removal of impurities by flotation enhanced the combination of fiber and fiber. However, the removal of fines decreased the strength of the samples. These interactions resulted in fluctuation in tensile strength, burst strength, and tear strength after flotation. In summary, the industrial-scale test results supported the findings of other literature (Su et al. 2018b). High-frequency dispersion and flotation recovery of pulp fiber from MOW fine screen reject improved tensile strength, tear strength, and burst strength.

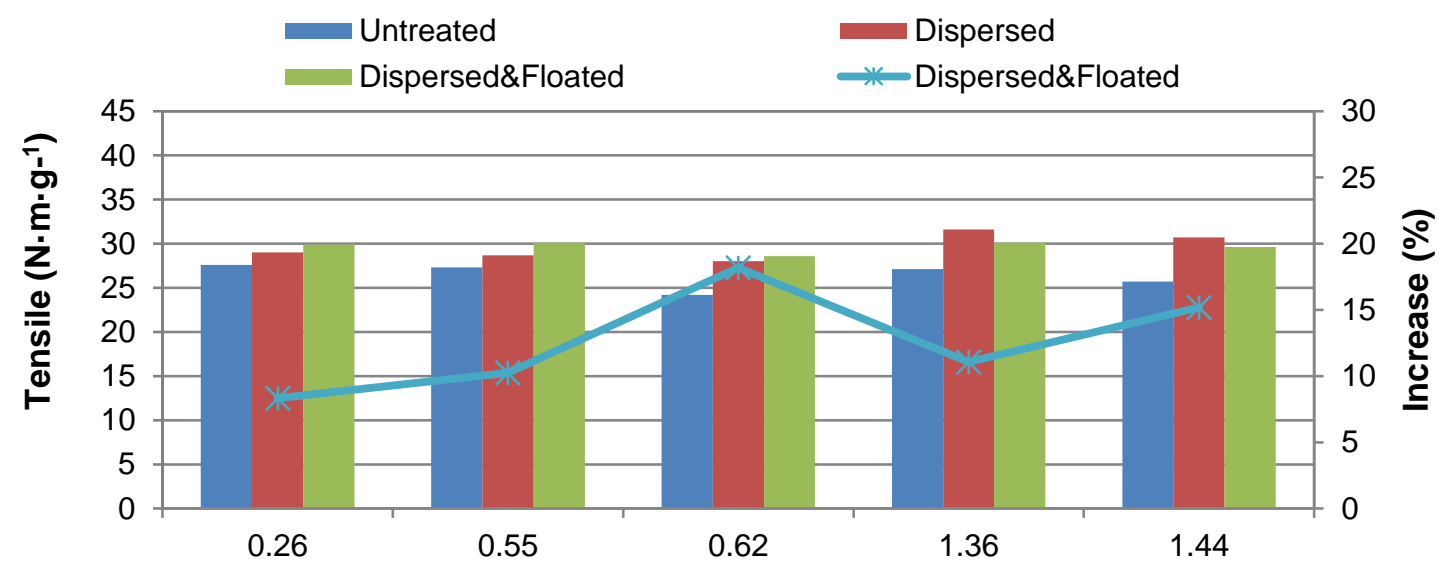

Consistency (\%)

Fig. 5. The tensile strength of samples with different running consistencies $(0.26 \%, 0.55 \%$, $0.62 \%, 1.36 \%$, and $1.44 \%)$

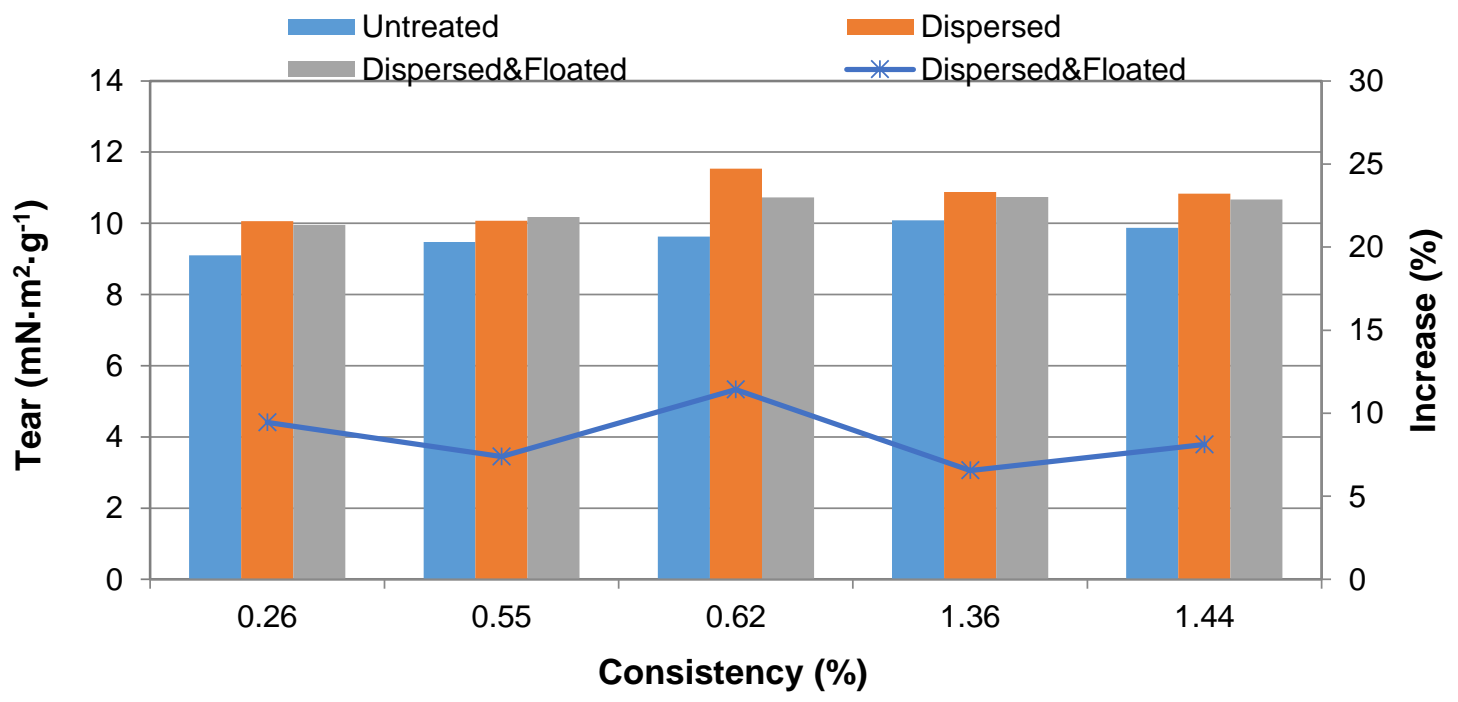

Fig. 6. The tear strength of samples with different consistencies $(0.26 \%, 0.55 \%, 0.62 \%, 1.36 \%$, and $1.44 \%)$ 


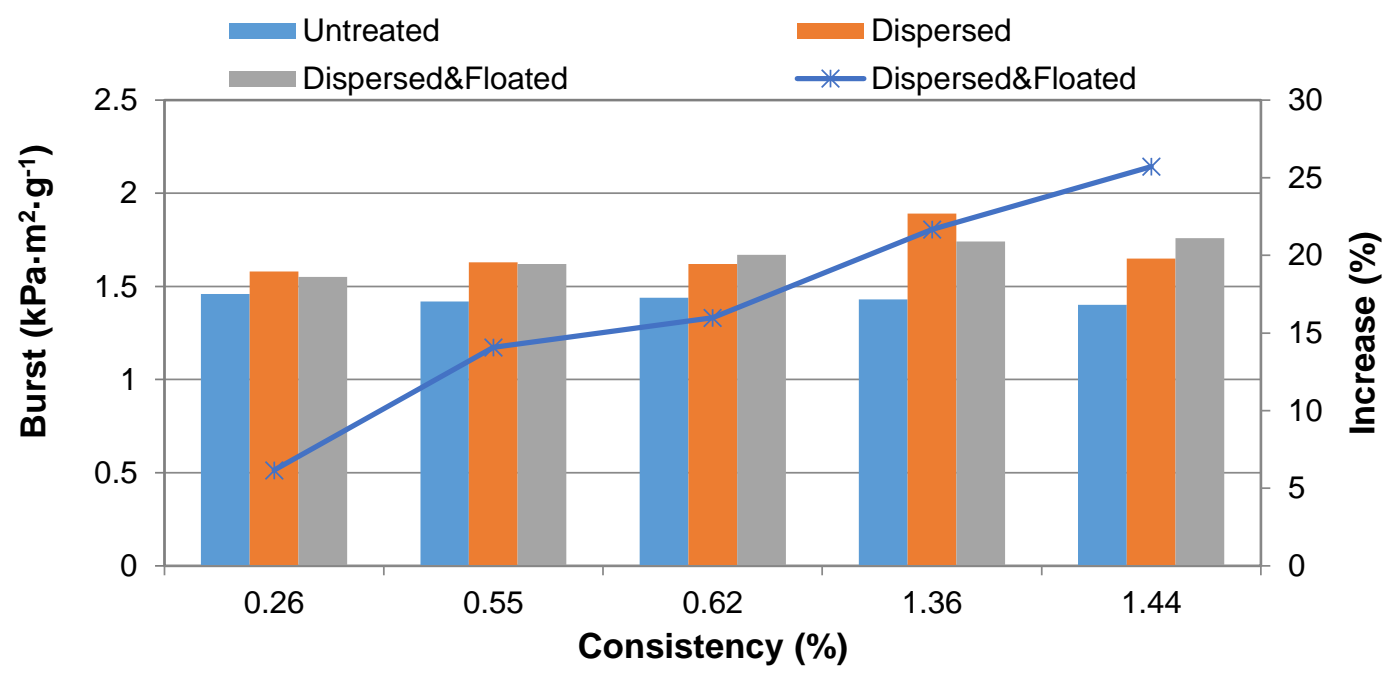

Fig. 7. The burst strength of samples with different consistencies $(0.26 \%, 0.55 \%, 0.62 \%, 1.36 \%$, and $1.44 \%)$

\section{Energy Consumption}

Energy consumption is the main operating cost of the fine screen rejects recovery system, and it directly determines the economic feasibility of the technology. The energy consumption of the system was measured separately during testing. The energy consumption of the slurry pulp at different concentrations and per ton of pulp (as BDT) is shown in Fig. 8.

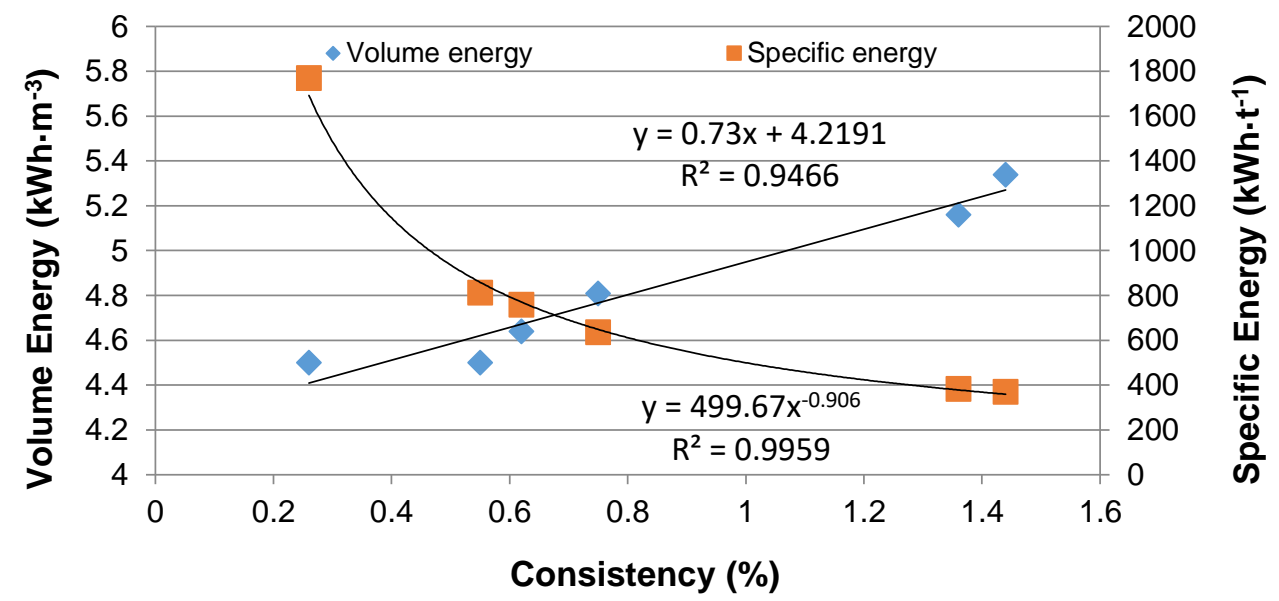

Fig. 8. Volume energy and specific energy correlations with different consistencies $(0.26 \%$, $0.55 \%, 0.62 \%, 1.36 \%$, and $1.44 \%)$

Figure 8 shows that the volume energy consumption $(y)$ of the fine screen reject treatment system increased with increased operating concentration $(x)$, and a good linear relationship was observed: $y=0.73 x+4.2191\left(\mathbf{R}^{2}=0.9466\right)$. The energy consumption per ton of dry pulp $(y)$ decreased with increasing operating concentration $(x)$, and energy consumption per ton dry pulp and operating concentration had a power function relationship: $y=499.67 x^{-0.906}\left(\mathbf{R}^{2}=0.9959\right)$.

Su et al. (2020). "Fiber recovery from screen rejects," BioResources 15(3), 6420-6430. 6428 


\section{CONCLUSIONS}

1. The industrial-scale test results of the fine screen reject recovery system were consistent with those in the literature, as the system effectively removed large macrostickies and dirt specks from the fine screen reject, and the removal efficiency of macrostickies and dirt specks reached $95.7 \%$ to $98.3 \%$ and $51.5 \%$ to $76.8 \%$, respectively. High-frequency dispersion had a remarkable effect on the removal of large macrostickies and dirt specks regardless of operating concentration from $0.26 \%$ to $1.44 \%$.

2. The fine screen reject recovery system improved the physical strength of the pulp. The tensile index increased 5.1\%, the tear index increased 6.6\%, the tear index increased $11.4 \%$, and the tear resistance index increased $6.6 \%$ to $25.7 \%$.

3. The volume energy consumption $(y)$ of the fine screen reject treatment system increased with increasing concentration $(x)$, and a good linear relationship was observed: $y=0.73 \times 4.2191\left(\mathrm{R}^{2}=0.9466\right)$. Specific energy consumption $(y)$ decreased with increasing concentration (x), and a power function relationship was observed: $y=$ $499.67 x^{-0.906}\left(\mathrm{R}^{2}=0.9959\right)$.

\section{ACKNOWLEDGMENTS}

This project was funded by the China Science and Technology Exchange Center (Grant No. 216YFE0114700).

\section{REFERENCES CITED}

Chen, Jia-Xiang. (2003). "Research progress in pulping technology of waste paper," China Pulp and Paper 22(2), 43-48. CNKI:SUN:ZGZZ.0.2003-02-022.

China Paper Association (2017). "2016 Annual report of China's paper industry," China Paper Newsletters 6, 8-18.

Fan, S-J., Mahmoud, M. S., Biao, Wen., Su, Z-H., and Yu, Zhang. (2018). "Bioelectric activity of microbial fuel cell during treatment of old corrugated containerboard discharges," BioResources 13(2), 3545-3553. DOI: 10.15376/biores.13.2.3545-3553.

General Office of the State Council of the People's Republic of China (2017). "Implementation plan of prohibiting foreign garbage entry and promoting solid waste import management system reform [2017-07-28]," (http://zfs.mep.gov.cn/gz/bmhb/gwygf/201707/t20170728_418692.shtml), Accessed 28- 07- 2017.

Long, L., and Wen-Ying, F. (2014). "Research progress of old newspaper deinking," China Pulp and Paper 33(9), 62-69. DOI: 10.3969/j.issn.0254-508X.2014.09.013.

Ministry of Environmental Protection of the People's Republic of China (2017).

"Announcement on issuing the catalogue of import waste management (2017)[201708-16]," (http://www.mee.gov.cn/gkml/hbb/bgg/201708/t20170817_419811.htm), Accessed 16- 08- 2017.

Ministry of Environmental Protection. GB 16487.4-2017. "Environmental protection

Su et al. (2020). "Fiber recovery from screen rejects," BioResources 15(3), 6420-6430. 
control standard for imported solid wastes as raw materials -Waste and scrap of paper or paperboard," China Standard Press, Beijing, China.

Su, Z-H., Biao, W., Fan, S-J., Yu, Zhang., and Wang, H-T. (2018a). "Fiber recovery technology of ONP fine screen reject," Paper Science and Technology 37(6), 10-14. CNKI:SUN:GDZZ.0.2018-06-002.

Su, Z-H., Biao, W., Zhang, Y., Fan, S-J., and Peng, F. (2018b). "Study on fiber recovery from mix office fine screen reject," China Pulp and Paper 37(10), 8-12. DOI: 10.11980/j.issn.0254-508X.2018.10.002.

Su, Z-H., Mahmoud, M. S., Fan, S-J.,Yu, Z., and Peng, F. (2019). “Combustion properties of mixed black liquor solids from linter and reed pulping," BioResources 14(4), 8278-8288, DOI: 10.15376/biores.14.4.8278-8288.

Article submitted: March 23, 2020; Peer review completed: June 20, 2020; Revised version received and accepted: June 29, 2020; Published: July 6, 2020.

DOI: 10.15376/biores. 15.3.6420-6430 